\title{
Computational Fluid Dynamics at work - Design and Optimization of Microfluidic Applications
}

Krühne, Ulrich; Bodla, Vijaya Krishna; Møllenbach, Jacob; Laursen, Steen; Theilgaard, Naseem; Christensen, Leif H.; Gernaey, Krist

\section{Publication date:}

2012

Document Version

Publisher's PDF, also known as Version of record

Link back to DTU Orbit

Citation (APA):

Krühne, U., Bodla, V. K., Møllenbach, J., Laursen, S., Theilgaard, N., Christensen, L. H., \& Gernaey, K. (2012). Computational Fluid Dynamics at work - Design and Optimization of Microfluidic Applications. Poster session presented at 11th International Symposium on Process Systems Engineering, Singapore.

\section{General rights}

Copyright and moral rights for the publications made accessible in the public portal are retained by the authors and/or other copyright owners and it is a condition of accessing publications that users recognise and abide by the legal requirements associated with these rights.

- Users may download and print one copy of any publication from the public portal for the purpose of private study or research.

- You may not further distribute the material or use it for any profit-making activity or commercial gain

- You may freely distribute the URL identifying the publication in the public portal 


\section{Computational Fluid Dynamics at work Design and Optimization of Microfluidic Applications}

Ulrich Krühne ${ }^{a}$, Vijaya K. Bodlaa ${ }^{a}$ Jacob Møllenbach ${ }^{b}$, Steen Laursenc, Naseem Theilgaard ${ }^{d}$, Leif H. Christensene and Krist Gernaey.

aDept. of Chemical and Biochemical Engineering , Technical University of Denmark, Søltofts Plads, Building 227, DK-2800 Kgs. Lyngby, Denmark

b Smart Biosystems ApS, Hvildkildevej 48, DK-2400 Copenhagen NW, Denmark

c IVF SYD Vendersgade 24, DK-7000 Fredericia Denmark

d Danish Technological Institute, Center of Plastics Technology, Gregersensvej 1, DK-2630 Høje Taastrup, Denmark

e Danish Technological Institute, Center for Microtechnology and Surface Analysis, Gregersensvej 1, DK-2630 Høje Taastrup, Denmark

\section{Motivation}

Computer aided process engineering has many potential applications. One of the most eloquent ways of applying computational tools is to predict the performance of systems and to use the predictions for optimization of future designs. Computational fluid dynamics (CFD) has throughout the last decades undergone a breathtaking development and is used increasingly in industrial applications. The prediction quality has indeed reached such a level of maturity that many scientific and industrial users increasingly apply the method for a broad range of applications. A well suited field of use for CFD supported design or analysis is in the area of fluid dynamic conditions with low Reynolds numbers. Typical applications can be found where the flow channel geometries are in the range of micrometers, giving the field the name microfluidics. From a mathematical point of view the equation system is reduced to the Navier Stokes equation and hence no turbulent terms have to be implemented. Therefore the prediction quality of the CFD models is expected to supply excellent qualitative and quantitative results for such systems. This poster presents three different case studies applying CFD in designing microfluidic systems.

\section{Results}

1. Scaffold 3D geometry design and optimization

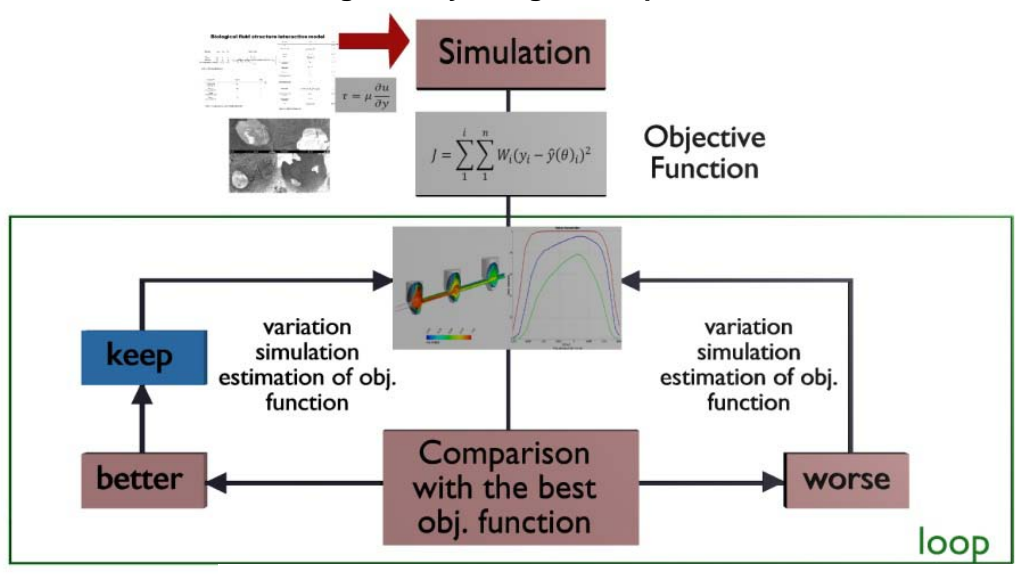

A biological model [1] has been implemented into a commercial CFD platform (ANSYS ${ }^{\circledR}$ CFX) considering the beneficial impact of shear stress. Hence the cost function is optimized considering the maximal area and the optimal shear strain rate (SSR). A similar approach is described in [2]

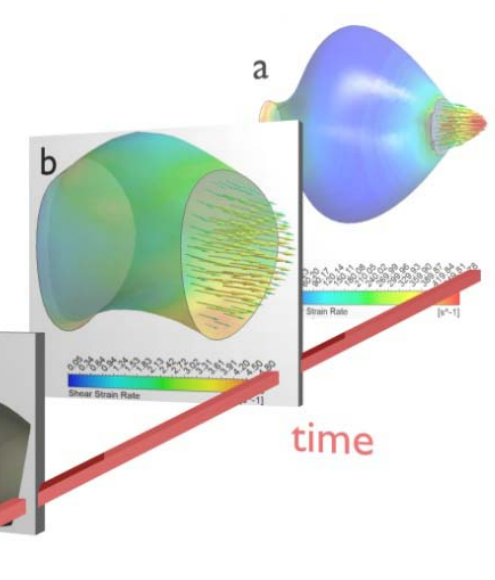

a. Starting geometry with shear strain rate (SSR) plot;

b. intermediate result;

c. Final 3D geometry in optimized form. The new form is optimized with respect to the homo-geneous shear strain rate field as well as for the maximum surface area.

\section{Conclusions}

\section{CFD as software sensor}
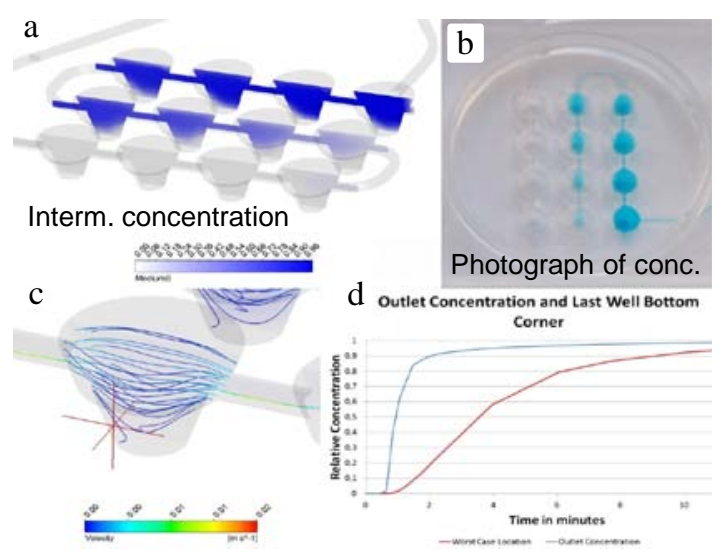

Streamlines and worst Transient conc. (outlet and Case placement (cross) worst case)

3. The design of a microfluidic biocatalytic reactor

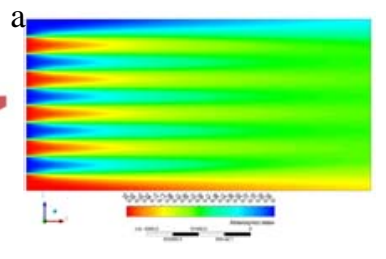

Simulation of the interdigitated fluidic array (fast diffusion coefficients for both media);

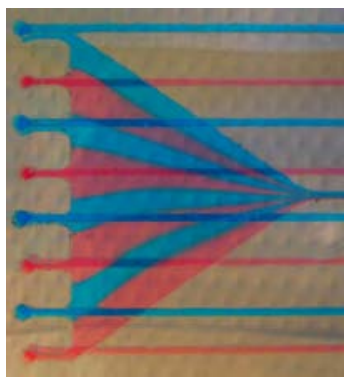

Experimental setup with dyed liquid streams. Obviously the diffusion of the dye is relatively slow compared to the simulated substances.

CFD has been demonstrated as a powerful tool for development of new theoretical qualitative insight or quantitative understanding of difficult measurable key components in microfluidic applications. Due to the lack of turbulent flow conditions in miniaturized systems the CFD results have a high predictive quality and results can be obtained with relatively small effort

\section{Acknowledgments}

The work was partly financed by the Danish Research Council for Technology and Production and the 'AUTOBONE' Strep RTD project supported by the EC under the 6th Framework Programme under contract number 505711-1.

\section{References}

[1] U. Krühne et. al., 2010, A transient 3D-CFD model incorporating biological processes for use in tissue engineering, Micro and Nanosystems, 2 (4), $249-260$. 